\title{
The reduction of tariffs under the "linear" and "Swiss formula" in the new WTO round: Impacts on the EU sugar regime
}

\author{
Ellen Huan-Niemi \\ MTT Economic Research, Luutnantintie,00410 Helsinki.ellen.huan-niemi@mtt.fi
}

\section{Introduction}

Despite on-going negotiations on the various facets of agricultural support and protection in the World Trade Organisation (WTO), differences still remain between the key protagonists over the issue of market access and reduction of import tariffs. One of the key issues is the formula for achieving reductions in agricultural tariff rates, which are generally acknowledged to be too high. Under the "linear" approach, which was adopted in the Uruguay Round, high and low tariffs are both reduced at the same percentage rate, leaving the highest tariffs still at prohibitive levels even after any percentage reduction has been made. The Swiss formula recognises the wide diversity in the current range of tariffs, from in excess of $100 \%$ in some cases to little more than zero in others. Using a "coefficient" mechanism, high starting tariffs are reduced at a faster rate than lower tariffs, thus addressing the issue of tariff "peaks" for certain heavily protected products which has been a particular concern of the Cairns Group. The Cairns Group proposal would give developed countries five years to reduce their tariffs to $25 \%$ or lower, with a $50 \%$ "down payment" cut made in the first year.

The WTO circulated the first draft of "modalities" for further commitments in the forthcoming WTO round to WTO member governments in February 2003. However, WTO member governments failed to agree on a framework of "modalities" for the future agriculture trade reform at the Fifth WTO Ministerial Conference in Cancun, Mexico held on September 2003. Along with almost all the other negotiations under the Doha Development Agenda, the agriculture talks are scheduled to end by 1 January 2005. This timetable was agreed in November 2001, at the Fourth WTO Ministerial Conference in Doha, Qatar.

\section{Methodology}

Three different tariff reduction formulas are used for the projections of "border protection" for EU sugar (Table 1). The first formula is the Uruguay Round formula with a "linear" $36 \%$ on average and a minimum of $15 \%$ reduction in standard tariffs. The second formula is the "Swiss formula" proposed by the Cairns Group with standard tariffs not exceeding 25\% after tariff reduction and a 50\% "down payment" cut made in the first year. Finally, the third formula is the tariff reduction formula proposed by the WTO or the so-called "Harbinson Proposal" (WTO 2003) with a "linear" 60\% on average and a minimum of $45 \%$ reduction for tariffs greater than $90 \%$ in ad-valorem basis.

TABLE 1: Tariff reduction formulas used in the projections for "border protection"

\begin{tabular}{|l|l|}
\hline Uruguay Round formula & $\begin{array}{l}\mathrm{t}_{1}=[(1-\mathrm{a}) * \mathrm{t} 0], \text { where parameter a }=0.36 \text { (on } \\
\text { average } 36 \% \text { reduction in tariffs) or parameter } \mathrm{a}= \\
0.15(\text { with a minimum } 15 \% \text { reduction in tariffs) }\end{array}$ \\
\hline Swiss formula & $\begin{array}{l}\mathrm{t}_{1}=(\mathrm{a} * \mathrm{t}) /(\mathrm{a}+\mathrm{t} 0), \text { where parameter a }=25 \text { (no } \\
\text { individual tariff exceeds } 25 \%)\end{array}$ \\
\hline Harbinson Proposal formula & $\begin{array}{l}\mathrm{t} 1=[(1-\mathrm{a}) * \text { to }] \text { for all agricultural tariffs greater } \\
\text { than } 90 \% \text { in ad-valorem basis, where parameter a }= \\
0.60 \text { (on average 60\% reduction in tariffs) or } \\
\text { parameter a }=0.45 \text { (with a minimum 45\% reduction } \\
\text { in tariffs) }\end{array}$ \\
\hline
\end{tabular}

The on-going negotiation process in the WTO under the Doha Development Agenda is assumed to be completed by January 2005. Hence, the new WTO round is assumed to begin in marketing year 2005/2006 and end in marketing year 2009/2010, over an assumed five-year implementation period.

The base year for the "linear" reduction of the Uruguay Round and "Harbinson Proposal" formulas is 2004/2005, whereby the applied "specific tariff rate" for raw sugar in 2004/2005 (a continuance of Uruguay Round's final bound rate in marketing year 2000/2001) is further reduced. 
The base year for the "Swiss formula" reduction is also 2004/2005, but the "specific tariff rate" for raw sugar is converted into ad-valorem equivalent for further tariff reduction.

In the calculations for further tariff reductions, the Uruguay Round and "Harbinson Proposal" formulas for "linear" reduction are applied directly to the EU's specific tariffs for raw sugar. However, under the "Swiss formula" for tariff reductions, the specific tariffs are converted into ad-valorem equivalent. The ad-valorem equivalent tariff for EU raw sugar is calculated by dividing the final bound tariff rate for raw sugar (EUR 339) with the average world market price for raw sugar from 1995 to 2001 (Table 2). After the conversion, tariffs under the "Swiss formula" are calculated on the basis of world market price multiplied by the reduced ad-valorem tariff for the particular marketing year.

TABLE 2: World market prices and EU's ad-valorem tariff equivalent for raw sugar

\begin{tabular}{|l|c|c|c|c|c|c|c|}
\hline World Market & $\mathbf{1 9 9 5 / 1 9 9 6}$ & $\mathbf{1 9 9 6 / 1 9 9 7}$ & $\mathbf{1 9 9 7 / 1 9 9 8}$ & $\mathbf{1 9 9 8 / 1 9 9 9}$ & $\mathbf{1 9 9 9 / 2 0 0 0}$ & $\mathbf{2 0 0 0 / 2 0 0 1}$ & Average \\
\cline { 2 - 7 } Price in Euro & 214 & 210 & 232 & 152 & 143 & 250 & 200 \\
\hline
\end{tabular}

Source: USDA 2003, author's calculations.

Sensitivity towards the fluctuation of world market prices for raw sugar (FOB Caribbean Price/New York No. 11) is considered by using both the Organisation for Economic Co-operation and Development (OECD 2003) and the Food and Agricultural Policy Research Institute (FAPRI 2003) projections of world market prices for raw sugar. Overall, the FAPRI projections are more optimistic compared to the OECD projections for the world prices of raw sugar. The world market prices are given in the form of free on board (FOB), but the projections are calculated on the basis of cost, insurance, \& freight (CIF).

The volatility of the Euro has been high during the past two years (2001 to 2003), moving from one Euro equals to USD 0.80 towards USD 1.20. In year 2001, the "weak Euro" scenario was dominant, but in year 2003 the "strong Euro" scenario is dominant. The projections' sensitivity towards the strength of the Euro is measured by using two scenarios -- a "weak Euro" scenario (EUR $1=$ USD 0.80) and a "strong Euro" scenario (EUR $1=$ USD 1.20). Under the scenario of a "strong Euro" (when world market prices are low), projections are made to show the additional border protection provided by the "Special Safeguard Provisions" for sugar. The safeguard duties are calculated according to the specifications given under Article 5.5 of the Uruguay Round Agreement on Agriculture. WTO members are allowed to imposed additional duties automatically when import prices fall below a certain level or if import volumes rise above a certain level by invoking the "Special Safeguard Provisions" as a safeguard measure .

The EU has proposed to continue the use of the "Special Safeguard Clause" (SSG) or "Special Safeguard Provisions" for both developed and developing countries. Conversely, the Cairns Group has proposed to discontinue the use of the "Special Safeguard Provisions" for developed countries. Furthermore, the Harbinson Proposal also includes the proposition to discontinue the use of the "Special Safeguard Provisions" for developed countries, and only developing countries are allowed to use this safeguard measure. Therefore, the projections are divided into three different sections: 1) the Uruguay Round formula for further tariff reduction and the "Special Safeguard Provisions" are allowed as a safeguard measure for developed countries; 2) the "Swiss formula" according to the Cairns Group Proposal for further tariff reduction, but developed countries cannot utilise the "Special Safeguard Provisions" as a safeguard measure; and 3) the formula according to the Harbinson Proposal for further tariff reduction, and the "Special Safeguard Provisions" are not allowed as a safeguard measure for developed countries.

\section{An example of projection outcomes}

\section{Projections according to the Harbinson Proposal}

The EU will certainly lose its border protection for raw sugar in the assumed new WTO round if the standard tariff for EU raw sugar is further reduced by $60 \%$ according to the Harbinson Proposal. In addition, a $25 \%$ cut in the intervention price for raw sugar is not sufficient to provide border protection for both "weak Euro" and "strong Euro" scenarios (Appendix: FIGURE 1). In order to maintain the border protection for raw sugar under this reduction percentage, the intervention price need to be lowered by $45 \%$ or nearly half. 
The EU can also choose the minimum reduction percentage of $45 \%$ under the Harbinson Proposal. Similar to the $60 \%$ reduction in tariff, the EU will lose its border protection for raw sugar in the assumed new WTO round if the standard tariff for EU raw sugar is further reduced by $45 \%$. Though, the EU will be able to sustain its border protection with a $25 \%$ cut in the intervention price for raw sugar under the scenario of a "weak Euro," but incapable of maintaining its border protection under the scenario of a "strong Euro" (Appendix: FIGURE 2). In this case, the intervention price need to be lowered by $35 \%$ in order to maintain the border protection for raw sugar.

\section{Conclusions}

The outcome for a multilateral agreement under the WTO is still unclear, but it is clear that the chances for the EU sugar regime to escape reform are slim. Even if the Uruguay Round formula is accepted as the reduction formula for sugar in the new WTO round, the minimum reduction rate of $15 \%$ may be deleted. The minimum reduction rate may be rejected because market access may not improve in the new WTO round if there is a possibility to reduce tariff by only $15 \%$.

The chances are very slim, but the EU sugar regime can avoid reform or cut in the intervention price in the new WTO round with at least three conditions: 1) the Uruguay Round formula will be accepted as the reduction method in the new WTO round and the EU can use the minimum reduction rate of $15 \%$ for sugar; 2) world sugar prices will recover in the future; and 3) both developed and developing countries are allowed to use the "Special Safeguard Provisions."

If the Cairns Group Proposal for tariff reduction is implemented in the new WTO round, the EU sugar regime will have to go through drastic reforms. The EU is considered to be one of the highest cost producers in the world sugar market. Many of the sugar producers in the EU would not survive reforms that will require a 67\% or two-thirds drop in price. The Cairns Group Proposal will most probably end the EU's dominance as a major exporter and producer in the world sugar market, but the EU will still remain as a major importer of sugar in the world market.

If the Harbinson Proposal for tariff reduction is implemented in the new WTO round, the EU may choose the minimum reduction percentage of $45 \%$ (instead of 60\%) for sugar since sugar is considered as a "sensitive commodity." In this case, the intervention price for sugar is required to be lowered by $35 \%$, which is only $10 \%$ more than the $25 \%$ percent cut suggested earlier by the EU Commission for reforming the EU sugar regime. Thus, the EU sugar regime may be able to survive a $35 \%$ cut in intervention price, contrary to the statement given by the EU agriculture commissioner, Franz Fischler ${ }^{1}$. The EU sugar regime would not come to an end if the Harbinson Proposal is accepted, although the one-third cut in price would be hard to swallow for the high cost sugar producers in the EU.

\section{References}

Agra Europe 2003. Frosty EU reception for new WTO paper. Agra Europe Weekly, 14 February 2003 (Issue no: AE2041).

FAPRI 2003. Sugar Outlook, FAPRI 2003 World Agricultural Outlook, Food and Agricultural Policy Research Institute. Available at http://www.fapri.iastate.edu/pubs/brfbk.html

OECD 2003. World Sugar Projections, OECD Agricultural Outlook 2003-2008, Organisation for Economic Cooperation and Development.

Sugaronline. Independent guide to sugar prices, sugar news and sugar products and services worldwide. Available at www.sugaronline.com/quotes/ldp.htm

USDA 2003. Sugar and Sweetener: Data Tables, Briefing Rooms, Economic Research Service, U. S. Department of Agriculture. Available at http://www.ers.usda.gov/briefing/sugar/Data/data.htm

WTO 2003. First Draft of Modalities for the Further Commitments (Revision -- 18 March 2003), Negotiations on Agriculture, Committee on Agriculture, World Trade Organisation. Available at www.wto.org. TN/AG/W/1/Rev.1

\footnotetext{
${ }^{1}$ Commissioner Fischler was particularly adamant about the effects of the Harbinson Proposal on the EU's Common Market Organisation (CMO) for sugar, saying it would face certain destruction if the ideas were to be adopted. "If this proposal is supported, the EU's sugar CMO is at an end. Nothing is left," he warned (Agra Europe 2003).
} 


\section{Appendix}

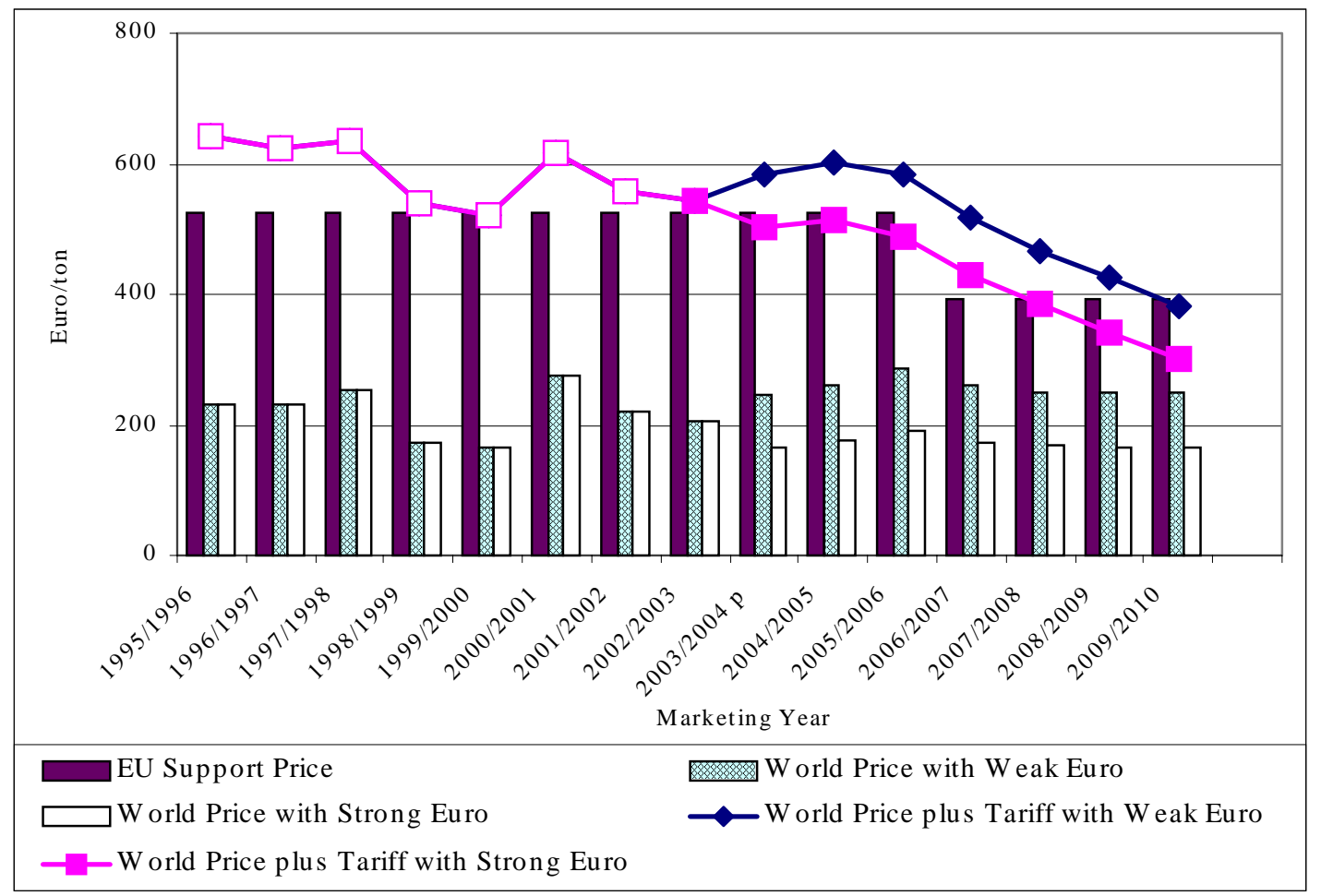

FIGURE 1: Harbinson Proposal formula -- The level of protection for EU raw sugar in the new WTO round after linear $60 \%$ reduction in standard tariff and a $25 \%$ cut in the intervention price for raw sugar in 2006/07. Source: OECD 2003, USDA 2003, Sugaronline, author's calculations.

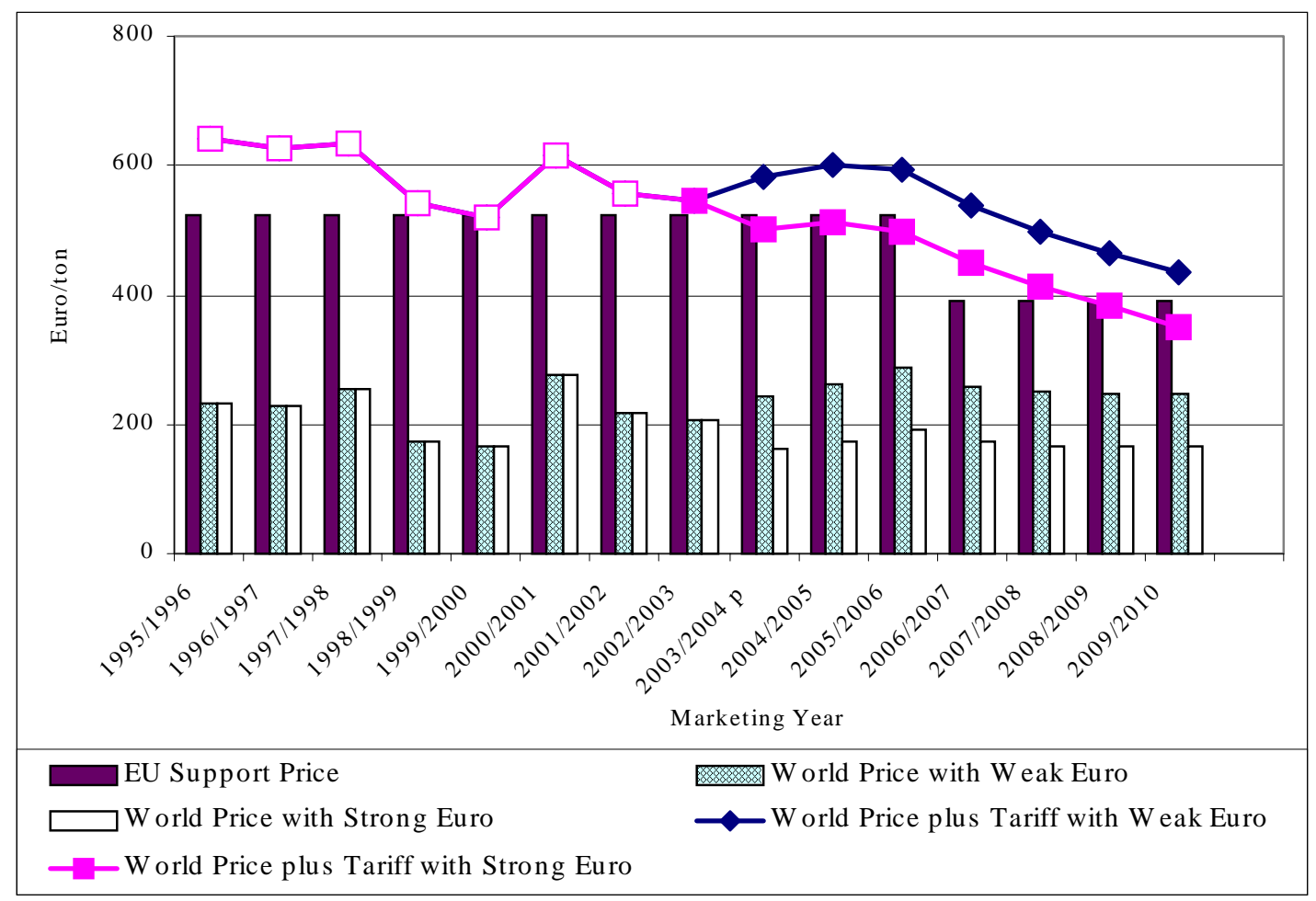

FIGURE 2: Harbinson Proposal formula -- The level of protection for EU raw sugar in the new WTO round after linear $45 \%$ reduction in standard tariff and a $25 \%$ cut in the intervention price for raw sugar in 2006/07. Source: OECD 2003, USDA 2003, Sugaronline, author's calculations. 